\title{
Implementasi pendidikan karakter dan pengajaran bahasa Indonesia di Sekolah Dasar Inklusi Kota Madiun
}

\author{
V. Teguh Suharto ${ }^{1,}$ a dan Nur Samsiyah ${ }^{2, ~ b}$ \\ a Program Studi Pendidikan Bahasa dan Sastra Indonesia, Universitas PGRI Madiun \\ b Program Studi Pendidikan Guru Sekolah Dasar, Universitas PGRI Madiun \\ ${ }^{1}$ Suharto_teguh@unipma.ac.id*; nurssya08@gmail.com \\ *korespondensi penulis
}

\begin{tabular}{ll}
\hline Informasi artikel & \\
\hline Sejarah artikel: & \\
Diterima & $:$ 20 Mei 2020 \\
Revisi & : Oktober 2020 \\
Dipublikasikan & $:$ Oktober 2020 \\
\hline
\end{tabular}

Kata kunci:

karakter

pengajaran bahasa

sekolah inklusi

\begin{abstract}
ABSTRAK
Pembelajaran merupakan kegiatan yang dirancang untuk proses belajar siswa. Pembelajaran merupakan proses interaksi antara siswa dan guru dengan memanfaatkan sumber belajar dalam lingkungan belajar. Salah satu tujuan pembelajaran untuk membangun watak dan budi pekerti siswa. Dalam membangun watak tidak dapat dilakukan sekali jadi, tetapi memerlukan proses yang panjang. Watak dalam istilah lain ada yang menyebutkan sebagai karakter atau tabiat. Dengan mengimplementasikan pendidikan karakter pada sekolah inklusi diharapkan siswa memiliki potensi yang sama dan tidak merasa dibedakan dengan anak normal. Pendidikan inklusi memerlukan lingkungan yang baik agar siswa dapat meneladani dan melakukan pembiasaan dari kecil serta memberikan penguatan. Lingkunganlah yang pertama dan utama membentuk karakter anak sejak dari dalam kandungan, lahir, dan sampai dewasa. Melalui keteladanan orang tua dan lingkungan (keluarga-masyarakat-sekolah), proses intervensi dan proses habituasi karakter terbentuk. Pendidikan inklusi atau anak berkebutuhan khusus sangatlah unik dan khusus. Pada beberapa aspek dibutuhakan penyesuaianpenyesuaian, ketelatenan, dan semangat dari guru dalam membimbing, menuntun, dan memberi teladan. Dalam artikel ini perlu dikaji pembentukan karakter, pendidikan karakter, jenis-jenis karakter, pendidikan inklusi, dan implementasi pendidikan karakter pada sekolah inklusi agar dapat memperoleh gambaran yang jelas bagi semua pihak.
\end{abstract}

Key word:

character,

language teaching

inclusive schools

\begin{abstract}
Learning is an activity designed for the student learning process. Learning is a process of interaction between students and teachers by utilizing learning resources in a learning environment. One of the learning objectives is to build the character and character of students. In building character, it cannot be done once, but requires a long process. Character in other terms is said to be character or character. By implementing character education in inclusive schools, students are expected to have the same potential and do not feel that they are differentiated from normal children. Inclusive education requires a good environment so that students can emulate and habituate from childhood and provide reinforcement. The environment is the first and foremost shape of the child's character from the womb, birth, and until adulthood. Through parenting and the environment (family-community-school), the process of intervention and character habituation is formed. Inclusive education or children with special needs is very unique and special. In some aspects, adjustments, patience, and enthusiasm from the teacher are needed in guiding, guiding, and modeling. In this article, it is necessary to study character building, character education, types of character, inclusive education, and the implementation of character education in inclusive schools in order to get a clear picture for all parties.
\end{abstract}

Copyright (C) 2018 Universitas Ahmad Dahlan. All Right Reserved

\section{Pendahuluan}

Pembelajaran adalah proses belajar mengajar yang dilakukan oleh guru dan siswa. Menurut
Winataputra (2007) proses pembelajaran yang merupakan salah satu jantung pendidikan yaitu mengembangkan kemampuan, membangun watak dan peradaban bangsa. Proses pembeljaran tidak hanya 
dilakukan di sekolah saja, namun lingkungan keluarga memiliki pengaruh terhadap watak atau tabiat siswa. Persoalan yang sering muncul adalah ketidakseimbangan antara aspek intelektual dan nonintelektual, sehingga pendidikan hanya menyentuh sisi akademis yang berakibat kurang mengembangkan kreativitas dan mengesampingkan masalah karakter siswa. Samani dan Hariyanto (2012) menyatakan bahwa akar dari semua perbuatan dan tindakan jahat dan buruk, terletak pada hilangnya karakter. Karakter yang baik akan membentuk manusia yang baik dan bermoral.

Sampai dewasa ini pendidikan karakter pada generasi muda bangsa belum mencapai hasil yang diharapkan. Hal itu terbukti dengan fenomenafenomena yang tampak, misalkan secara umum siswa masih berada dalam keterpurukan emosional. Perkembangan teknologi justru tidak sekaligus menjadikan siswa berkarakter baik, namun sebaliknya dampak negatif teknologi sangat dirasakan oleh orang tua yang memiliki siswa di sekolah dasar. Seperti yang dapat kita lihat, banyaknya kasus pencurian, pemerkosaan, kasus narkoba, tindak kekerasan dan penganiayaan dan pernikahan dini yang terjadi di lingkungan sekitar kita yang berasal dari kemajuan teknologi. Siswa lebih tertarik menggunakan gadget daripada bermain dengan teman yang lain. Sehingga karakter semakin lama akan semakin luntur. Dalam hal komunikasi, sering dijumpai komunikasi yang kurang pantas diucapkan baik dalam lingkungan sehari hari secara langsung maupun komunikasi dalam media sosial yang sering menimbulkan berita hoaks. Sehingga dapat dikatakan bahwa untuk berkomunikasi dengan dengan baik harus memiliki etika dan kesantunan dalam bertutur kata. Dengan banyaknya pelanggaran norma berbahasa, maka berbahasa dengan baik tidak hanya dilakukan dalam forum resmi namun secara luas baik dengan siapapun di manapun dan kapanpun. Pelanggaran dalam berbahasa sering ditemui ketika berhadapan dengan piranti teknologi sebagai alat komunikasi. Abidin (20I5) menjelaskan setiap penutur akan berhati-hati ketika memilih kata dan bentuk wacana yang berkaitan dengan konteks berbahasa dan berkomunikasi diantaranya situasi, tujuan.

Berdasarkan banyaknya kesulitan dan tantangan dewasa ini dan ke depan, maka sangat perlu ditanamkan pendidikan karakter. Pendidikan karakter perlu dikembangkan dengan nilai-nilai budaya sejak dini. Karakter menurut Kemendikbud (2010a) suatu moral yang dibangun atas kebaikan yang dilandasi dengan nilai-nilai. Penanaman karakter tidak hanya sebagai materi ajar yang bersifat hafalan atau pegangan guru dan tidak hanya diajarkan melalui mata pelajaran agama saja. Pendidikan karakter tidak hanya mengajarkan salah benar, tetapi menanamkan kebiasaan baik pada siswa sehingga menjadi paham (domain kognitif) tentang salah benar, mampu merasakan nilai dan biasa melakukannya (domain perilaku) (Abidin, 2010). Olah hati (etika), olah pikir (literasi), olah raga (kinestika), dan olah karsa (estetika) terintegrasi secara total saling memperkuat yang dimiliki oleh seseorang baik secara psikologis maupun sosio-kultural.

Pembentukan karakter yang paling dominan berasal dari lingkungan melalui keteladanan, intervensi dan pembiasaan yang dilakukan secara terus menerus. Lingkunganlah (yang pertama dan utama) membentuk karakter anak sejak dari dalam kandungan, lahir, dan sampai dewasa. Melalui keteladanan orang tua dan lingkungan (keluargamasyarakat-sekolah), proses intervensi (melalui pembelajaran, pemodelan, dan penguatan) dan proses habituasi (melalui pensuasanaan, pembiasaan, dan penguatan) karakter terbentuk. Selain itu karakter dapat dilakukan dengan menggunakan game (Putri, 2019). Ibarat orang tua dan lingkungan itu menggambar lukisan di kertas yang masih kosong. Peristiwa ini dilakukan secara informal (di rumah), nonformal (di masyarakat) melalui tegur sapa dan interaksi sehari-hari dengan lingkungannya, maupun formal (di sekolah). Kita ingat teori belajar behavioritik (stimulus-respon), sesuatu akan menjadi kebiasaan dan tertanam dalam jiwa jika dihadirkan penguatan (Suharto: 2013, 20I5). Jika suatu respon terhadap stimulus dibenarkan oleh lingkungan karena penguatan, anak akan merasa benar, ia akan mengulang, akhirnya menjadi kebiasaan yang menjadi ciri sifat kepribadiannya. Dan jika tidak pernah dikritik sifat itu akan permanen di dalam jiwanya. Semoga orang tua dan lingkungan akan selalu memberikan stimulus positif untuk membentuk kepribadian yang baik pada anak. Orang tua dan lingkungan diharapkan memiliki sikap yang positif dalam mengenalkan, nenanamkan, dan membentuk kepribadian anak sebab mereka telah memiliki nilainilai yang bersumber dari agama yang dianut, tradisi sosial budaya yang hidup di masyarakat, kebiasaan keluarga dari nenek moyang, dan lain sebagainya (Kemendiknas: 2010).

Dalam kurikulum nasional perencanaan dan pelaksanaan pendidikan budaya dan karakter menurut Puskurbalitbang (2010) dapat dilakukan dengan dengan (I) pengembangan diri seperti kegiatan rutin sekolah, kegiatan spontan, keteladanan dan pengkondisian, (2) pengintegrasian ke dalam mata 
pelajaran dan melalui budaya sekolah yang dapat dikerjakan secara bersama-sama. Sedangkan pembelajaran pendidikan karakter dapat dilakukan melalui kegiatan di kelas, sekolah ataupun dapat dilakukan dalam kegiatan ekstrakurikuler. Salah satu kegiatan implementasi pendidikan karakter dilakukan di sekolah inkluisi. Berdasarkan undang-undang dan peraturan pemerintah no. I7 tahun 2010 tentang pendidikan khusus salah satu bentuk pelayanan pendidikan bagi anak berkebutuhan khusus yaitu penyelenggaraan pendidikan inklusi. Dalam sekolah inklusi siswa yang memeliki kebutuhan khusus akan diberikan pelayanan, di didik dalam satu tempat dengan siswa normal untuk membantu mengembangkan bakat dan minat yang dimilikinya.

Penerapan pendidikan karakter dalam kelas inklusi di lingkungan sekolah, memerlukan kesiapan dari seorang guru atau tenaga pendidik yang memiliki kompetensi yang baik. Kesiapan guru merupakan suatu hal yang sangat penting, karena kelas Inklusi tersebut berbeda dengan kelas reguler pada umumnya, selain kesiapan guru yang merupakan faktor penting, fasilitas di dalam kelas Inklusi juga merupakan hal yang mendukung jalannya belajar pembelajaran pada kelas tersebut. Keadaan peserta didik serta sikap mereka juga merupakan pendorong pelaksanaan belajar mengajar pada kelas inklusi tersebut. Apalagi dari mereka tentunya memiliki kekurangan masingmasing, dan tidak sama antara satu dengan yang lainnya

Kembali pada desain induk bahwa pendidikan karakter dilakukan dengan strategi utama yaitu keteladanan, intervensi, pembiasaan yang dilakukan secara konsisten, dan penguatan (Depdiknas: 2008), maka semua komponen harus terintegrasi dalam pembelajaran khusunya di sekolah inklusi. Salah satunya dengan mengimplementasi pendidikan karakter dalam pembelajaran melalui pendekatan saintifik yang berorientasi pada berfikir kritis. Dengan mengimplementasikan pendidikan karakter pada sekolah inklusi diharapkan dapat meningkatkan potensi anak dari segi kognitif, afektif, psiomotor dan dalam interaksi sosial. Sehingga dapat membantu peserta didik berfikir, bersikap dan bertindak sesuai norma.

Pengertian karakter sendiri merupakan sifat kejiwaan, aklhak atau budi pekerti yang dimiliki oleh seseorang yang membedakan seseorang dari yang lain (Kamus besar Bahasa Indonesia, 2008a). Karakter adalah watak, tabiat, akhlak, atau kepribadian seseorang yang terbentuk dari hasil internalisasi berbagai kebajikan (virtues) yang diyakini dan digunakan sebagai landasan untuk cara pandang, berpikir, bersikap, dan bertindak (Puskur Balitbang, 2010). Karakter tidak hanya ada dalam pendidikan tetapi karakter ada dalam diri tiap manusia, sehingga baik buruknya perilaku yang dapat dilihat oleh orang lain. Menurut Samani dan Hariyanto (20I2) karakter dimaknai sebagai cara berfikir dan perilaku yang khas tiap individu untuk hidup dan bekerja sama dalam lingkup keleuarga, masyarakat bangsa dan negara. lebih lanjut dikatakan bahwa individu yang berkarakter baik dapat membuat keputusan dan siap mempertanggungjawabkan setiap akibat dari keputusannya. Berdasarkan beberapa pendapat tersebut dapat disimpulkan bahwa karakter merupakan akhlak, watak, cara bersikap dan berfikir dalam lingkungan keluarga, masyarakat dan negara.

Lickona (2013) menyebutkan komponen dari karakter diantaranya pengetahuan moral, perasaan moral, tindakan. Samani dan Hariyanto (20I2) menjelaskan bahwa karakter merupakan cara berfikir dan berperilaku yang khas pada setiap individu untuk hidup dan saling bekerja sama dalam keluarga, masyarakat dan bangsa. Lebih lanjut dikatakan bahwa karakter sebagai nilai dasar yang membangun yang dipengaruhi oleh hereditas dan lingkungan yang diwujudkan dalam sikap dan perilakunya sehari-hari. Sedangkan Winton (2010) menekankan pendidikan karakter pada usaha guru dalam mengajarkan nilai nilai pada siswa. Kristalisasi nilai-nilai tersebut dapat ditemukan nilai utama yang terdiri dari: relegius, integritas, nasionalis, gotong royong, dan mandiri. Sekolah dapat melalkukan pengebangan dengan membangun nilai prakondisi sebelumnya berdasarkan situasi dan kondisi sekolah masing-masing. Puskur Balitbang (2010) mendefinisikan prinsip dalam pengembangan pendidikan karakter diantaranya (I) berkelanjutan dari awal sekolah dasar hingga sekolah menengah, (2) melalui mata pelajaran, pengembangan diri dan budaya sekolah, (3) nilai tidak diajarkan tetapi dikembangkan, (4) Proses pendidikan dilakukan peserta didik secara aktif dan menyenangkan.

Sekolah inklusi merupakan bentuk pelayanan pendidikan bagi anak yang memiliki kebutuhan khusus tanpa memandang fisik, intelegensi, sosial, emosional dan kondisi lainnya agar dapat belajar bersama siswa normal (Pratiwi, 2015). Sekolah inklusi memberikan pelayanan tanpa membedakan hak anak sebagai peserta didik baik siswa normal maupun yang berkebutuhan khusus. Inklusi berasal dari bahasa Inggris "inclution" yang menyatukan anak yang normal dengan anak berkebutuhan khusus. Pendidikan inklusi merupakan suatu pendidikan, di mana semua siswa yang tergolong memiliki kebutuhan khusus dapat diterima di sekolah reguler yang berlokasi di daerah tempat tinggal mereka dan mendapatkan berbagai pelayanan pendukung dan pendidikan sesuai dengan kebutuhanya. Sebagaimana 
yang ditegaskan melalui surat edaran Dirjen Dikdasmen No.380 UU.

Kebijakan di atas bukanlah tanpa maksud, anakanak yang berkebutuhan khusus yang awal mula ditampung di SLB (sekolah model segregasi) mengalami kesulitan beradaptasi dengan keluarga setelah pulang ke rumah. Ketika anak bersatu dengan teman-teman sebaya dan keluarga mereka merasakan sebagai orang asing. Dalam aspek administrasi memang mudah, tetapi dari segi anak akan merugikan karena kurang menjamin kesempatan anak untuk mengembangkan potensi secara optimal (Direktoral PLB: 2004). Membijaksanai kondisi ini, gagasan sekolah inkusi ini merupakan solusi terbaik, merupakan gagasan terkini untuk mewadahi perkembangan anak. Pendidikan inklusi ini tidak boleh hanya diserahkan ke sekolah, pihak-pihak terkait harus ambil bagian. Hal ini karena pendidikan inklusi akan gagal jika tidak ada partisipasi dari pihakpihak yang terkait termasuk orang tua anak (Buchori dalam Hendriani: 20I I).

Memperhatikan pedoman pendidikan luar biasa (Direktorat PLB: 2004; Deplhie: 2005; Semiawan: 1997) perencanaan pendidikan inklusi memperhatikan kurikulum yang sesuaikan pada aspek kebutuhan waktu, isi materi pelajaran, proses pembelajaran, sumber belajar, lingkungan, dan pengelolaan kelas. Kelas dapat dibagi ke dalam kelas terapi (dengan kurikulum omisi), kelas pendampingan (dengan kurikulum substitusi), dan kelas inklusi (dengan kurikulum duplikasi/modifikasi) sesuai kebutuhannya (Haryati, 2012). Kurikulum omisi dilaksanakan dengan mengurangi materi pelajaran atau meniadakan materi tertentu sehingga dapat dilakukan dengan substitusi dengan mengganti kurikulum yang setara dengan siswa normal. Sedangkan modifikasi bagi anak tuna grahita dan duplikasi bagi anak tunanetra, tunarungu yang IQ-nya setara dengan anak rata-rata.

Mata pelajaran bahasa Indonesia adalah salah satu dari 6 (enam) mata pelajaran pokok di sekolah dasar dalam kurikulum 2013 (KI3). Pembelajaran bahasa Indonesia diberikan di sekolah secara terintegrasi antara aspek pengetahuan, keterampilan, dan sikap dengan pembelajaran literai dan pendidikan karakter, integrasi tiga unsur yang terpadu. Pembelajaran bahasa Indonesia diberikan dengan pendekatan saintifik berbasis keterampilan berpikir tingkat tinggi (HOTs). Langkah-lagkah pembelajaran mengikuti pendekatan saintifik sebagai berikut: (I) mengamati, siswa melakukan observasi (membaca teliti teks atau pengamatan objek) untuk menemukan fakta sesuai objek analisis; (2) menanya, siswa mumupuk rasa ingin tahu melalui perumusan masalah/ mengajukan pertanyaan sesuai objek analisis; (3) mengumpulkan informasi, siswa mengumpulkan data/informasi melalui eksperimen, membaca ekstensif, dan lain-lain untuk mencari jawaban rumusan masalah/pertanyaaan; (4) mengasosiasi/menalar, siswa memproses, menelaah, dan menganalisis informasi untuk menetapkan solusi/ pokok temuan/ jawaban sesuai objek analisis; (5) mengkomunikasikan, siswa menyampaikan hasil simpulan analisis hasil pengamatan kepada orang lain secara tulis maupun lisan.

Untuk mengikuti pelajaran dengan pendekatan saintifik diperlukan hight order thingking (HOTs) yang meliputi critical thingking, creative and inovative thingking, collaboration, dan communication (4C). HOTs harus dimiliki siswa pada era revolusi industri 4.0 ini karena saat ini dan ke depan dunia kerja menuntut cara berfikir kreatif-inovatif-kritis, kemampuan pemecahan masalah; bekerja secara kolaboratif, komunikatif, menguasai informasi, melek teknologi informasi. Kemampuankemampuan itu menuntut siswa memiliki integritas, inisiatif, motivasi, kerja sama dalam tim, etika, kemauan belajar, komitmen, tangguh, komunikasi, jujur, berargumen logis, dan insan yang beriman dan bertaqwa kepada Allah yang Maha Kuasa (Suhardjono, 2018: 9; Sajidan, 20I8b: I-3).

Berfikir tingkat tinggi merupakan keterampilan yang meminimalkan aspek ingatan dan hafalan. Menurut Kemendikbud (2016) menekankan pada transfer konsep ke konsep lain, pemprosessan dan penerapan informasi, mencari kaitan dari informasi yang berbeda, dan penyelesaian masalah serta menelaah ide dan informasi secara kritis. Jika disandingkan dengan urutan tingkatan kognitif menurut Anderson dan Krathwohl (200I), maka HOTs terletak pada tahap analisis, evaluasi, dan mengkreasi; MOTs terletak pada tahap pemahaman dan aplikai; dan LOTs terletak pada tahap mengetahui. Kemampuan berpikir tingkat tinggi (HOTs) mengandung cirri utama ialah meminimalkan aspek ingatan atau pengetahuan. Ciriciri berpikir tingkat tinggi ialah aktifnya kemampuan: menemukan, menganalisis, menciptakan metode baru, mereflksi, memprediksi, erargumen, mengambil keputusan yang tepat, berbasis permasalahan kontekstual; stimulus menarik; tidak rutin (Depdiknas, 2013)

Pendekatan saintifik berbasis keterampilan berpikir tingkat tinggi (HOTs) diterapkan dengan melalui model-model pembelajaran inovatif. Untuk implementasi pendekatan saintific Depdiknas 
merekomendasi empat model pembelajaran, yaitu model pembelajaran problem based learning (PBL), Project learning, inquirí, dan discovery. Memperhatikan pola induk pendidikan karakter nasional yang memperhatikan proses intervensi (pembelajaran, pemodelan, dan penguatan) dan proses habituasi (pensuasanaan, pembiasaan, dan penguatan) dan pada akhirnya menjadi karakter (Kemendiknas: 2010), maka dengan diterapkannya model pembelajaran inovatif sesuai pendekatan saintifik berbasis HOTs diharapkan dapat membentuk karakter peserta didik seperti yang diharapkan.

Tenaga kependidikan dapat terdiri dari guru umum dan guru pendidikan khusus (GPK). Guru GPK bertugas menyususn instrumen asesmen, membangun komunikasi dengan guru lain dan orang tua anak (untuk konseling keluarga), memberikan bimbingan khusus agar siswa mencapai tujuan belajar. Peserta didik. Peserta didik pendidikan inklusif dapat terdiri dari anak tuna grahita (retardasi mental), anak berkesulitan belajar spesifik, anak tunanetra, anak tuna rungu, anak tuna daksa (kelainan anggota tubuh/gerakan), anak tuna laras (mengalami gangguan emosi/ perilaku), anak autis, anak lambat belajar, dan anak berbakat (gifted and talented) (lihat juga atau of Rachmayana: 2013). Sarana-prasarana. Sarana-prasarana disediakan secara khusus sesuai kondisi dan perkembangan anak berkebutuhan khusus. Keuangan. Keuangan sangat diperlukan sebagai untuk penyelenggaraan, pembiayaan kegiatan identifikasi kecacatan dan asesmen potensi input siswa yang melibatkan ahli dan psikiater (Koswara: 2013). Penempatan ABK dapat dilakukan dengan bercampur pada kelas reguler atau kelas siswa normal, atau dengan kelas khusus atau intensif.

Memperhatikan pedoman pendidikan luar biasa (Direktorat PLB: 2004) proses pembelajaran pada pendidikan inklusi mempertimbangkan rancangan PPI atau program pembelajaran individu individualized education program disingkat IEP. PPI ini disusun dengan memperhatikan tata kelola kelas, proses pembelajaran, materi ajar, sumber belajar dan evaluasi. Pelaksanaan kegiatan pembelajaran ini memperhatikan teknik komunikasi dengan siswa dan dilakukan dengan menerapkan pendidikan karakter dengan cara bersikap yang baik, terbuka serta memiliki simpati pada siswa ABK agar interaksi dapat berjalan lancar. Penilaian dan evaluasi dilakukan dengan memperhatikan kondisi dan perkembangan anak. Kemajuan belajar ditinjau lebih intensif untuk menentukan perlunya perbaikan dan memberikan pengayaan untuk menyempurnakan kekurangan selama pembelajaran di kelas inklusi.

\section{Metode}

Jenis penelitian yang dilakukan adalah penelitian kualitatif dengan metode deskriptif. Penelitian dilakukan pada tiga SD inklusi kota Madiun tahun pelajaran 2019/2020 yaitu SD negeri Sukosari, SD Negeri 02 Taman, dan SD Negeri 02 Winongo. Pemilihan tempat didasarkan pada sekolah yang dijadikan tempat merupakan sekolah inklusi. Sumber data adalah informan, yaitu kepala sekolah, guru dan siswa. Data diambil dengan teknik wawancara dan observasi pembelajaran di kelas. Pemeriksaan Keabsahan data dengan triangulasi sumber, member check dan FGD kemudian dianalisis.

\section{Hasil dan Pembahasan}

Implementasi pendidikan inklusi di kota Madiun terdapat tida sekolah dasar (SD) inklusi, yaitu SD Negeri Sukosari, SD Negeri 02 Taman, dan SD Negeri 02 Winongo. Dari eksplorasi sekilas ditemukan kondisi praktik sebagai berikut.

I. Tataran Kebijakan

Kebijakan di tingkat kota dapat dilihat pada SK kepala Dikbud kota Madiun nomor 42040I.I04/2345/20I3 tanggal I4 Juni 2013 tentang penyelenggaraan pendidikan inklusi. Sk tersebut berisi penetapkan sekolah inklusi dan tanggung jawabnya dalam penyelenggaraan pendidikan inklusi.

Kebijakan di tingkat provinsi tertuang pada SK kepala dinas provinsi Jatim nomor I88.4/6536/I03.3/20I3 tanggal 24 Oktober 2013 tentang penunjukan master teacher pengembang pendidikan inklusi tingkat kota/kabupaten di Jatim. Pada SK ini ditetapkan tugas master teacher: (a) sebagai guru pembimbing khusus di tempat bertugas; (b) melakukan identifikasi asesmen dan penyusunan PPI; (c) melakukan modifikasi kurikulum sesuai kebutuhan ABK; (d) melakukan evaluasi program pembelajaran dan tindak lanjut; (e) membuat laporan program dan pengembangan peserta didik berkebutuhan khusus secara berkala; (f) melaporkan hasil pelaksanaan tugas selaku guru pembimbing khusus inklusif ke kepala dikbud.

Berdasarkan schedulle kelompok kerja pendidikan inklusi (KKPI) Kota Madiun tahun 2018, KKPI mengadakan kegiatan-kegiatan sebagai berikut: (a) peningkatan mutu SDM penyelenggara melalui sosialisasi, workshop (identifikasi-asesmen, pengembangan pembelajaran-modifikasi kurikulum, pameran/gebyar, dan pembekalan GPK; (b) regulasi penyelenggaran dengan evaluasi-penetapan sekolahGPK-pusat sumber-sekolah model, penyusunan standar layanan; (c) networking melalui sosialisasi ke stakehorlers-MoU/MoA dengan dinas/ kemenag/PT/denkes/densos; $\quad$ (d) plotting 
penyelenggaraan dengan workshop dan bantuan sekolah model/LPK model; (e) pusat data informasipublikasi melalui pendataan anak, SLB-sekolah inklusi dari aspek guru-GPK-sarpras-jenjang, pembuatan WEB; ( $\mathrm{f}$ ) penguatan pusat sumber; $(\mathrm{g})$ dokumentasi dan pelaporan; (h) penyusunan grand desain pengembangan pendidikan inklusi; (i) monitoring dan evaluasi; ( $j$ ) pencanangan program sebagai kota pendidikan inklusi

2. Tataran Impementasi

a. Perencanaan Pembelajaran Individu (PPI)

PPI di Kota Madiun disusun berdasarkan KI3.

Dari studi dokumentasi terhadap beberapa PPI ditemukan model sajian sebagai berikut.

(I) PPI diawali dengan deskripsi identitas PPI yaitu nama sekolah, kelas dan semester, tema, waktu, nama dan jenis kebutuhan siswa

(2) KI dan KD, serta indikator ditulis berdasarkan KI3 update 20I7, yaitu KI ditulis lengkap dan KD-indikator disajikan dalam matriks.

(3) Deskripsi tujuan sudah berdasarkan kriteria ABCDC. Contoh " setelah disajikan video tentang lagu daerah siswa dapat mengikuti dan menyanyikan sesuai irama dengan percaya diri”. Tujuan ditulis dalam satu kalimat terintegrasi. Di sekolah-sekolah daerah lain, deskripsi karakter ditulis terpis ah setelah nomor-nomor tujuan selesai ditulis dengan diawali "penekanan pembentukan karakter".

(4) Deskripsi materi pelajaran disajikan dengan menyebutkan pokok-pokok materi misalnya: (I)

mengikuti lagu yang didemonstrasikan, (2) menyapa teman, (3) sila pancasila. Penyesuaian bahan pelajaran (duplikasi kurikulum) untuk ABK disajikan include pada urutan kegiatan inti.

(5) Deskripsi pendekatan dan metode disampaikan cukup rinci dengan menyebut: pendekatan (santifik), strategi (cooperatif learning), menggunakan (flash card) dan demonstrasi.

(6) Kegiatan pembelajaran disusun dengan kolom pendahuluan, inti, dan penutup.

Pada kegiatan awal diurutkan kegiatan membuka dengan salam, berdoa, menyiapkan sikap siswa, menyanyikan lagu Garuda Pancasila atau lagu nasional lain, dan membiasakan membaca 15 menit. Deskripsi karakter ditulis menyatu pada sub urutan tersebut, misalnya pada berdoa tertulis "kelas dilanjutkan berdoa bersama untuk menanamkan sikap religius dan dipimpin oleh satu orang untuk menanamkan keberanian atau percaya diri”. Pada urutan kegiatan menyanyi ditulis "Menyanyikan ... untuk menanamkan pendidikan karakter berupa nasionalisme”. Pada kegiatan pembiasaan membaca ditulis "untuk meningkatkan kegiatan literasi”.

Pada kegiatan inti disajikan secara terintegrasi syntax dari pendekatan-metode, penguatan karakter, dan pendampingan bagi ABK. Untuk syntax ditulis urutan dengan kata-kata secara eksplisit yaitu (I) ayo membaca, (2) ayo berlatih, (3) ayo bernyanyi, (4) ayo bercerita, (5) ayo mengamati, dan (6) ayo mencoba.

Pada urutan kegiatan ayo membaca, misalnya, disitu dideskripsikan kegiatan guru sebagai berikut.

Guru duduk di depan siswa dan membaca teks keluarga Udin secara pelan-pelan

I. Guru mengulangi kata-kata yang penting satu persatu

2. Siswa menirukan kata-kata yang diucapkan guru

3. Guru menjelaskan tentang sikap religius dengan cara mensysukuri nikmat Tuhan

Pada urutan kegiatan ayo berlatih, misalnya, disitu dideskripsikan

Siswa dibimbing guru menghubungkan gambar lambang dengan bunyi sila Pancasila (PPI SDN 02 Taman: 2017).

Pada kegiatan penutup disajikan urut kegiatan (I) siswa saling bercerita, (2) siswa dan guru mencermati kekurangan selama pembelajaran, (3) penarikan kesimpulan dan penguatan materi, (4) memberikan penguatan karakter, (5) siswa mengumpulkan tugas (sumber: PPI SDN 02 Taman: 2017).

(7) Penilaian lengkap dengan instrumenya baik pengetahuan, sikap dan keterampilan. Instrumen dalam menilai sikap dilengkapi dengan jurnal penilaian sikap spiritual dan sosial. Penilaian pengetahuan sudah lengkap dengan soal-soal pengetahuan dan kuncinya. Penilaian keterampilan sudah lengkap dengan perintah melaksanakan kegiatan dan lembar observasinya (PPI SDN 02 Taman: 2017).

b. Kesulitan-kesulitan

Pelaksanaan Pembelajaran Individu

Pelaksanaan pembelajaran selalu diusahakan agar dipraktikan berdasarkan PPI yang telah disusun. Guru kelas, guru mata pelajaran, dan GPK telah melakukan usaha penyesuaian baik aspek kurikulum (materi) maupun cara penyampaian serta bimbingan, namun kendala selalu ada dan ditemukan sebagai berikut:

(I) Kendala dalam penyesuaian materi pelajaran

Materi Pelajaran yang ada disekolah inklusi sama dengan materi pelajaran untuk sekolah reguler, yaitu materi-materi yang pakem telah ditetapkan oleh pemerintah. Sehingga materi tersebut kurang tanggap terhadap kebutuhan anak yang berbeda. Guru harus 
berupaya menyesuaikan materi pelajaran yang ada dalam kurikulum sesuai dengan kemampuan ABK

(2) Kendala dalam penyesuaian dan cara penyampaian materi pembelajaran

Dari masing-masing ketunaan membutuhkan cara layanan yang berbeda dalam menyampaikan materi. Guru terbentur kemampuan yang terbatas dalam bidang itu juga terbatasnya jumlah tenaga, sedangkan pembimbingan terhadap ABK adalah pembimbingan individu. GPK harus betul-betul memahami karakter dan cara belajar dari masingmasing $\mathrm{ABK}$.

(3) Kendala dalam pembimbingan ABK

Guru kesulitan dalam membimbing ABK apabila GPK belum dekat dengan ABK secara kejiwaan maka akan sulit melakukan pembimbingan. Kondisi psikologis $A B K$ tidak stabil bila sebelumnya ada sesuatu yang kurang pas pada diri ABK maka pembimbingan juga sulit dilakukan. Sedangkan GPK tidak setiap saat bersama ABK.

(4) Kendala dalam melakukan evaluasi pembelajaran

Kondisi psikologis yang tidak stabil dari ABK menyebabkan evaluasi pembelajaran terkadang tidak sesuai dengan rencana dan waktu yang ditetapkan. Evaluasi dilakukan secara individu sehingga terbentur tenaga.

(5) Kendala pada peran serta orang tua ABK

Status sosial ekonomi serta pendidikan orang tua ABK yang masih rendah menyebabkan Tidak semua ABK mendapat dukungan dari orang tuanya. Kesadaran orang tua dari ABK akan pentingnya pendidikan masih rendah. Ada sebagaian orang tua ABK yang mempunyai perasaan malu dengan kondisi anak. Kurangnya pengetahuan orang tua dalam pembimbingan $\mathrm{ABK}$

(6) Kendala pada peran stakeholders

Peran stakeholder kurang karena sekolah inklusif disamakan dengan sekolah reguler lainya.

(7) Kendala pada manajemen keuangan dan sarana prasarana

Manajemen keuangan yang telah ditetapkan oleh pemerintah sama dengan sekolah reguler lainnya. Anggaran yang didapat sekolah sesuai dengan ketetapan dari pemerintah yaitu per anak dikalikan pagu yang telah ditetapkan. Jumlah murid sekolah inklusif lebih sedikit dibanding sekolah reguler sehingga dana yang masuk juga sangat terbatas. Hal ini menyebabkan sarana dan prasarana juga tidak sesuai dengan kebutuhan untuk masing-masing ABK. Sedang saspras yang dibutuhkan ABK 75\% harus menggunakan media dan juga ABK lebih kita utamakan keterampilan (hasil wawancara dengan guru dan kepala sekolah).
Dalam mengatasi hambatan dan kendala yang terjadi dalam pelaksanaan, maka dilakukan usaha sebagai beriku..

(I) meningkatkan SDM bagi GPK,

(2) mengadakan parenting,

(3) pendekatan dengan orang tua $\mathrm{ABK}$ untuk menghilangkan rasa malu,

(4) kerjasama dengan orangtua, komite, dinas terkait lembaga lembaga yang terkait dengan ABK, mencari sumber dana lainnya kalau memungkinkan dengan mengajukan proposal DAK (hasil wawancara dengan guru dan kepala sekolah).

\section{Persantunan}

Penulis mengucapkan terima kasih kepada seluruh pihak yang telah berperan dalam membantu penelitian ini. Selanjutnya kepada tim editor Bahastra yang telah membantu publikasi artikel ilmiah ini.

\section{Simpulan}

Berdasarkan hasil implementasi pada tataran program pembelajaran yang tercantum dalam pembelajaran individu sekolah inklusi di kota Madiun telah melaksanakan kegiatan pembelajaran yang mengacu pada pembentukan karakter siswa yang berkebutuhan khusus. Implementasi pembelajaran pendidikan karakter sesuai dengan kebijakan dinas pendidikan kota Madiun yang bekerja sama dengan surat keputusan dinas provinsi Jawa Timur. Meskipun terkendala pada proses penyampaian materi, sarana, peran masyarakat dan evaluasi, namun pengajaran bahasa Indonesia secara keseluruhan diimplementasikan secara baik oleh guru di SD negeri Sukosari, SD Negeri 02 Taman, dan SD Negeri 02 Winongo.

\section{Daftar Pustaka}

Direktorat Pendidikan Luar Biasa. 2004. Pedoman Penyelenggaraan Pendidikan Inklusi. Jakarta: Depdiknas

Haryati. 20I2. Model Layanan Pendidikan Inklusif. (dalam http://tutiharyatiI74722.gurusiana. id/article/ model-layanan-pendidikan-inklusif45I2900) diakses 26 Juni 2018

Hndriani, Wiwin. 20II. Keterlibatan Orang Tua dalam Pendidikan Anak Berkebutuhan Khusus. (dalam https://wiwinhendriani.com/20I I/08/04/ket erlibatan-orangtua-dalam-pendidikan-anakberkebutuhan-khusus/) diakses 26 Juni 2018.

Kemdiknas. 20I0. Desain Induk Pendidikan Karakter. Jakarta: Kementerian Pendidikan Nasional

. 20I I. Pedoman Pelaksanaan Pendidikan Karakter. Jakarta: Pusat Kurikulum dan Perbukuan 
V. Teguh Suharto, dkk | Implementasi pendidikan karakter dan....

Kemendikbud, 2017. Pedoman Kurikulum 2013 Update Tahun 2017. Jakarta: Pusat Kurikulum Nasional

Koswara. 2013. Pendidikan Anak Berkebutuhan Khusus Berkesulitan Belajar Spesifik. Jakarta: Metro Media

Program Pembelajaran Individu (PPI) di Sekolah Dasar Inklusi Kota Madiun

Putri dan Elvina. 2019. Penerapan metode game's untuk meningkatkan keterampilan

menulis dan karakter siswa pada mata pelajaran bahasa Indonesia. Jurnal UAD. BAHASTRA Vol. 39 No. 2 Tahun $2019 \mid 69-75$.

http://journal.uad.ac.id/index.php/BAHASTRA/article /view/I380I/7306

Rachmayana. 2013. Diantara Pendidikan Luar Biasa Menuju Anak Masa Depan. Jakarta: Metro Media

Schedulle Kelompok Kerja Pendidikan Inklusi (KKPI) Kota Madiun Tahun 2018

SK Kepala Dinas Pendidikan dan Kebudayaan Provinsi Jatim Nomor I88.4/6536/I03.3/2013 tanggal 24 Oktober 2013 tentang Penunjukan Master Teacher Pengembang Pendidikan Inklusi Tingkat Kota/Kabupaten di Jatim

SK Kepala Dinas Pendidikan Kebudayaan Pemuda dan Olah Raga Kora Madiun Nomor 420-40I.I04/ 2345/ 2013 tanggal I4 Juni 2013 tentang Penyelenggaraan Pendidikan Inklusi

Smith, J David. Ed. Mohammad Sugiarmin dan Mif Baihaqi. 2006. Inklusi Sekolah Ramah untuk Semua. Bandung: Nuansa

Suharto, V. Teguh. 2013. Pengantar Teori BelajarPembelajaran Bahasa dan Sastra Indonesia Berbasis Pengalaman. Salatiga: Widya Sari Press

20I5. Pengantar Teori Belajar-Pembelajaran Bahasa dan Sastra Indonesia Berbasis Pengalaman Edisi Revisi. Salatiga: Widya Sari Press

Suharto, V. Teguh. 2017. Radikalisme dan Kebhinekaan (Sekilas Problematika dan Alternatif Solusinya. Madiun: Kammi Madiun

Winataputra. 2007. Teori Belajar dan Pembelajaran. Jakarta: Universitas Terbuka

Abidin, Y. 2015. Pembelajaran Bahasa Indonesia Berbasis Pendidikan Karakter. Bandung: Refika Aditama

Depdiknas. 2008a. Kamus bahasa indonesia. Jakarta: balai pustaka

Kemendiknas. 20I0b. Kerangka Acuan pendidikan Karakter. Jakarta: Kemendiknas

Lickona, T. 20I3. Educating For Chaacter (Mendidik Untuk membentuk Karakter). Jakarta: Bumi Aksara

Samani dan Hariyanto. 20I2. Pendidikan Karakter. Bandung: Remaja rosdakarya
Wington. 20I0. Character Education. Implications for critical democracy. International critical chilhood policy studies, vol I

Puskur Balitbang. 20I0. Pengembangan Pendidikan Budaya Dan Karakter Bangsa. Jakarta: Kemendiknas

Pratiwi, JC (20I5) Sekolah Inklusi Untuk Anak Berkebutuhan Khusus: Tanggapan Terhadap Tantangan Kedepannya. Prosiding Seminar Nasional Pendidikan "Meretas Sukses Publikasi Ilmiah Bidang Pendidikan Jurnal Bereputasi," November,237-242.

http://jurnal.fkip.uns.ac.id/index.php/pip/arti cle/download/7725/555I

Kemendikbud. 2016. Panduan Bagaimana Pendidik Dapat Menulis Soal Yang Berkriteria Untuk Berfikir Tingkat Tinggi. Jakarta: Dirjendikdas 